\title{
Adopting an electronic text book for a postgraduate accounting course: An experiential study
}

\author{
Herbert P. Schoch, Hai Yap Teoh and Margaret Kropman \\ Macquarie University
}

\begin{abstract}
Students are becoming accustomed to using the Internet as an information source that supplements or replaces the normal institutional and classroom handout. However, the use of full electronic books through the Internet or $\mathrm{CD}$ instead of a printed full text book is a uniquely different experience, not only for these students but also for academics and their institutions. This study describes the initiative of constructing, publishing, prescribing and using an online text book for use by students in a postgraduate accounting course at an Australian university. The experience provides valuable insights that suggest the need for changes to hardware and software facilities in homes, offices and learning institutions, to students' expectations, and to purchase interfaces and text display, before electronic text books can be readily accepted as an alternative learning tool.
\end{abstract}

It is encouraging from the accounting students' feedback that there was no strong evidence of rejection of the e-book as a learning tool, despite the current technological difficulties associated with its use. This is a positive sign for the hopefully not too distant future use of this learning tool in accounting education.

\section{Introduction}

This paper reports the experience of adopting an e-book in a postgraduate accounting course at an Australian university. The paper is an expanded and revised version of a previously published conference paper (Kropman, Schoch \& Teoh, 2004). While the original much abbreviated version of the paper covered only the technical aspects of introducing and using an ebook, the focus of this paper is broadened to combine the technical issues of introducing an e-book with the experiences of students. This necessitated a wider review of the literature, covering both technological aspects and their application to accounting education. The paper expands the discussion of feedback from a survey of the students involved in the 
introduction of the e-book, and it allows us to draw implications for students, educators, publishers and university administrators about the use of technology in university education. Research on the integration of technology into the accounting curriculum is a relatively recent phenomenon. In 1998 Sangster \& Lymer discussed a new era in higher education due to the impact of the Internet, particularly the World Wide Web, and the resulting opportunities for new approaches to delivering and managing the educational process. We perceive the use of an electronic text book (e-book) as presenting such an opportunity, the focus of this paper.

While the spread and availability of electronic learning material has been considerable, the uptake of this by institutions has been slow (McNaught, Burd, Whithear, Prescott \& Browning, 2003). The authors cite access issues as one of the reasons for this poor uptake, and suggest that academics continue to prescribe printed text books as sources of information because of their own familiarity with this mode and because students do not demand a change. Hence, the printed text still remains the primary market commodity and the electronic materials "are just enhancements" (McNaught et al., 2003; p.73). The primacy of a printed text is also advocated by Carr-Chellman \& Duschatel (2000) who suggest that the ideal online course is characterised by, among other features, a blend of appropriate delivery media including study guide and printed text book.

The particular course that is the subject of this study had been taught face to face for a number of years and the plan was to develop it as an online offering for delivery to students in other countries. It was envisaged that all teaching materials, including an e-book (the latter with encouragement of a major book publisher), could be placed on the website for the course. The publisher's website indicates that similar online books and supplementary notes are supplied to students at academic institutions in the USA, Canada, Mexico and a number of other countries. Our paper describes the rationale for an e-book, how students could pay for and access the book, and reports the results of a survey of the students' perceptions and experiences with the e-book. The paper also raises issues that need to be considered in relation to electronic learning through e-books.

The motivation for the paper resulted from the classroom experience over a semester with the e-book. By documenting and assessing this experience, future users of such books, including students, academics, universities and book publishers may benefit from an awareness of the personal readiness of students in using such a text book, and the technical readiness of universities and publishers in catering to students' learning environments.

The remainder of the paper is organised as follows: the next section provides a review of the technological and the accounting literatures in 
relation to the use of technology for teaching. The actual experience in adopting an e-book at the university is then outlined, followed by the methods section and analysis of results. Issues for future consideration are discussed next, followed by a summary and conclusion.

\section{Literature review}

What is an e-book? An e-book is described in the literature as "a device specialised for displaying electronic reading material or is software designed to display such material" (Looney \& Sheehan, 2001; p.40), and elsewhere as "a handheld device that is specialised for displaying electronic versions of books" (Davies, Fitzsimmons \& MacLeod, 2001; p.1). Others use the term to describe the files containing the text that offer books online. Wikipedia (2006) attempts to standardise use of the word with: "An ebook is an electronic (or digital) version of a book. The term is used ambiguously to refer to either an individual work in a digital format, or a hardware device used to read books in digital format. Some users deprecate the second meaning in favour of the more precise 'ebook device'". The following paragraphs describe the evolution of e-books, illustrating how they became more user friendly, more easily accessible and more rewarding to owners of copyright.

E-book devices. Gemstar eBooks (2003), a UK product no longer available, marketed devices designed to carry and display electronic versions of books in a proprietary format. Their e-book files could be downloaded through any standard phone lines to e-book devices, and could also be downloaded to another battery powered portable reading device about the size of a paperback book, which could download from PCs. The application of the term e-book to hardware has become less relevant since the rise in popularity of laptops and Personal Digital Assistants (PDAs) that refresh from desktop computers.

Free e-books. Project Gutenberg (2005) claims to be the oldest producer of free electronic books (e-books or e-texts) on the Internet. Most of its collection of more than 13,000 eBooks produced by its hundreds of volunteers are long time, public domain literary works. All may be freely downloaded, read, and redistributed for non-commercial use. Files are saved in whatever formats the volunteers produce. For example, Jane Austen's Emma is available in plain text (.txt) and portable document format (.pdf) as well as other formats. Project Gutenberg proposes that digital rights protection produces "closed formats... will almost certainly be unreadable in just a few decades, when the companies now promoting them disappear, or lose interest, or decide to stop supporting them because they want to sell a replacement". 
E-book systems, Digital rights management. E-book software with in built controls for digital rights management (DRM) has been developed to protect files from unauthorised copying and printing and from misuse of the copyright licence. Two popular products on the market are Adobe Reader (2006) (formerly Adobe eBook Reader, which is now incorporated in Adobe Reader) and Microsoft Reader (2003). Adobe's eBook technology is based on its portable document format (PDF) and can be used on Windows and Macintosh computers, and Palm OS PDAs. Microsoft Reader eBooks, which are fully compatible with Windows 95 onwards as well as Pocket PC handheld devices, are electronic files that use ClearType technology for making words on the screen appear like words in a printed book. The DMR software for both Adobe and Microsoft can be downloaded free of charge and installed on computers where their e-books will be read.

E-book features. Popular features of e-books include:

- Pages displayed in full colour, with graphics and photos, and looking like the printed book.

- Pages that can be viewed in single or two-page format. Pages can be rotated when used on a laptop to simulate the traditional reading experience.

- E-books have full text search capability, text highlighting and annotation and bookmarking.

- Paging through the book with a navigator bar that indicates where the reader is in the book and allows the reader to use a mouse to move around the book.

- Embedded links offer supplementary reading

- The e-book can be downloaded and can be read immediately.

E-book marketing. Outlets for e-books are on the increase. Normal commercial booksellers include Amazon.com (2006) which publishes some e-books in Adobe Reader and others in Microsoft Reader. The ebrary (2006) site hosts publications for public, commercial and academic libraries. In the case of our e-book, the publisher stored online books in the ebrary library, and ebrary used Adobe ebook Reader to control DRM for the publisher. Other similar publishers include VitalSource (2005) which uses Acrobat Reader and has education as its target market, and Safari Books Online (2005).

Transition from printed text books to e-books. Looney et al. (2001) reported a third of students buy second hand text books, another third do not buy text books, and only $10 \%$ of all text book sales are to international markets "because of hard copy piracy as the costs of text books increase" (p.43). This suggests that the market for new text books must be unprofitable for both authors and publishers and that there is a need for a distribution paradigm such as the one surrounding the use of DRM software. The use of 
PDAs in USA educational institutions is increasing (Oliver \& Wright, 2002); it entails a new form of access known as channels, and links wireless and offline resources for use with PDAs and offers opportunities for use in education. Presumably DRM software is being developed for this use.

In general terms an e-book is an electronic version of a hard copy printed text book. For this paper, we use the current publishing concept of an 'ebook'; this encompasses the licence and DRM monitoring software that is purchased by a consumer in order to view and print the electronic files containing images that emulate the pages of a printed text book.

Not a great deal has been written about the use of e-books as a substitute for printed text books, although e-books are nothing new, with the first major application evident in 1971 (Kennedy, 2000). While the availability of electronic books across industries is growing, it is mainly for literary and government titles. Traditional publishers do not appear to have fully embraced this technology (Ardito, 2000). Ardito (2000) summarises the principal advantages and disadvantages of electronic books. Some of the advantages include: a single copy of a book can be loaded onto a server and made accessible to an unlimited number of users; the books can be printed or downloaded on demand and the danger of copyright infringement can be lessened. Disadvantages include difficulty of reading digitised print, and the loss of margin notes as new editions are published.

Readability of e-books and other onscreen materials has been discussed in a number of studies. For example, Armatas, Holt and Rice (2003) showed that students' preferred study mode was with print material because of its portability, because it could be annotated, and because Internet access was not easy and convenient. Many readers need to change their study habits to cope with online learning and, at least initially, many will resist this change. Hartley (2002) on the other hand found evidence that reading on screen did have some proponents - 70 of 152 (46\%) respondents (academics and related professionals) to an email query that involved reading approximately 900 words had chosen to read on screen, 76 (50\%) respondents read the message in print, and six $(4 \%)$ respondents read the message from both media. Thurstun (2000) discussed in detail the need for learners to adapt, and for writers to acknowledge the difficulties that readers are experiencing and to make adjustments to writing styles and visual effects to ease the problems of reading on screen.

Software features now available to facilitate using an e-book include turning pages, inserting bookmarks, highlighting and annotating, changing font size and text searching. Customers have the option of subscribing to a book for a fixed time or printing or copying. As an illustration, the Taylor \& Francis site (2001) lists their eBook formats. 
Birnbaum (2004) reports on surveys of graduate and undergraduate students in his education faculty. The graduates found e-books easy to use and navigate, fewer than $20 \%$ wanted to print the book, and they liked being able to simultaneously take notes on a word processor in another window. Undergraduates tended to want to make paper copies but disliked the lengthy time it took to print, and found using the e-book to be cumbersome. His undergraduate students had less experience using computers and the Internet than did the graduates and he further suggested that this might have affected the responses of the two groups. He continued that perhaps students' comfort levels with the technology would increase as use of the technology became more widespread and that their hesitancy would lessen.

Galbreath (2001) suggests that the e-book market is in the very early stages and there remain copyright and continuing technological issues to be resolved. But he goes beyond these two issues and argues that " perhaps the biggest issue is one of change - changing philosophies and ideals of professors, teachers, instructors, administrators, book publishers and even students" (p.56).

A review of the accounting education literature from 1991 to 2003 provided no evidence of any discussion of the use of e-books for teaching accounting courses. Educational technology itself received scant attention in the literature up to about 1998. Prior to this period, discussion of technology had yet to focus on Internet uses but, instead, focused mostly on tools such as spreadsheet applications (Alexander, 1996), computer exercises (Coppage, Sriram \& Baxedale, 1996), software packages (Wood, Cahill \& Hicks, 1997), module timetables and additional notes (Sangster \& Lymer, 1998). By 1998 there was also reference to the impetus to continually improve teaching methods and the desire to minimise costs, and that the adaptation of technology to teaching was seen as a way of reducing costs.

Concerns over access facilities to the Internet also began to surface. Sangster \& Lymer (1998) make reference to a potential problem with Internet access, arguing that while the Internet in theory creates for students an environment in which they can exploit this technology, few campuses maintain enough access points for a greatly increased level of student demand.

Early accounting research was also still very much involved with television issues, particularly the use of videos to support or supersede lectures. Bryant and Hunton (2000) advocated more research into the newer technologies for distance learning and hypermedia, while at the same time issuing a warning (p.17) that "accounting educators and researchers should not jump on the latest technology bandwagon simply because it is rolling 
nearby, [but] accounting educators should continually scan the horizon and incorporate solutions that are most likely to maximise the ultimate educational objective". This view is also supported by Reeves (1997) who cautions educators to be wary of claims by marketers of new technology that it is educationally effective, simply because they say it is.

By 2003, more evidence started to emerge of the phenomenal growth and increasing acceptance of the Internet as a viable alternative for educators in their delivery of subject content in accounting (De Lange, Suwardy \& Mavondo, 2003). This included lecture notes, bulletin boards, online assessment, chats and video summaries, all of which were favourably received by accounting students. Despite evidence of the increasing use of technology for higher education purposes, there are strong warnings of the risk of over reliance on technology to achieve educational outcomes. Judson and Sawada (2002), express the view that it is "the pedagogical practices of the instructor, not the incorporation of the technology as being key to student comprehension" (p.167). Kirkwood and Price (2005) support this view: "it is not technologies, but educational purposes and pedagogy that must provide the lead, with students understanding not only how to work with [information and communication technologies], but why it is of benefit for them to do so" (p. 257).

From our literature review it is clear that in both the educational and the accounting literatures up to the time of this study there was a paucity of research into the use of e-books as an emerging tool for teaching and learning in accounting and other disciplines.

\section{Justification for an e-book}

The need for such a book arose due to the uniqueness of the course. A variety of topics are included which no single existing hard copy text book covered. Hence, in collaboration with the publisher a custom publication was constructed comprising relevant chapters from four text books from the same publisher. However as the publishers require a minimum of 100 orders for a custom publication, and the course enrolment was at most 40, a printed version was not a viable option. At this point the option of an ebook was discussed, with special focus on the eventual offering of the course as a fully online course. The e-book was perceived to have four major advantages. Firstly, given the relatively small number of students enrolled in the course each semester an unlimited order quantity, e-book presented a viable option. Secondly, the University planned to deliver the course offshore. For online students in the course, access to the book electronically would overcome problems of logistics of shipping the book and assuring its receipt. Thirdly, students would pay the publisher directly, online, and course fees would not be inflated by the cost of course 
materials. Fourthly, the publisher's price for online access to the materials was \$AUD53 whereas an equivalent hard copy would cost \$AUD104. For these reasons, a decision was reached to have the publisher prepare a custom publication consisting of about 560 pages, and make this accessible via a linkage to the publisher's domain on the course website.

\section{Educational aspects of the technology}

At the time an e-book was considered for the course, the primary objective was linked to the expediency of providing students with a means of accessing text material which would not have been available in a convenient fashion in hard copy. The learning strategy for the on site students was to use preliminary reading followed by group research and report presentation at seminars. It was not considered relevant to offer these postgraduate students exercises in memory retention of the reading material in the form of online or electronic quizzes. Online researching skills, analysis and communication were developed as their projects progressed within their groups. Consequently it was intended that on site students should use the Internet only for information transmission. The learning strategy for off site students, when the need arises, will involve preliminary reading and group projects using online communication and presentation tools. Electronic delivery of the reading material was therefore a consequence of the unavailability of a hard copy text at a reasonable cost.

\section{Creating the e-book}

Since the publisher has electronic files containing the chapters of the four text books, it was not difficult to create a compendium of chapters online to form an e-book. The publisher is based in the USA where it collaborated with an electronic publishing company which publishes electronic e-books in a secure, password protected environment on the Internet. The electronic files are stored on the publisher's server and students use e-payment to buy access to the e-book. The files are stored in a proprietary format, ebrary, devised to read PDF files and use sophisticated viewing tools, that is used by three large international book publishers. Students view the material in the same layout as in printed editions.

\section{How a student accesses the e-book}

A student purchases viewing rights, not hard copy (paper) or soft copy (files on a CD). At the time of purchasing the viewing rights, a student is presented with two access choices:

\section{Downloading}

The e-book files download to a computer's hard drive where they reside permanently. On that computer the software (free, named the ebrary Reader) 
to read the files and monitor the number of accesses to the files is installed. Each time the e-book is accessed the student must use a password to log into the e-publisher's site and register themselves as reading. There is no need to download the e-book pages again, but the connection with the epublisher's site must exist while the student is reading the pages - the pages are not accessible unless the connection with the e-publisher site is active. The initial purchase buys a fixed number of page views, in this case twice the number of book pages, and additional page views can be purchased subsequently. Page view credits have no expiration date. The purchase buys the right to print as many pages as there are book pages, enough for one copy of each page of the e-book; however printing may be very slow.

A major advantage of this option is that there is only one download needed of the e-book files. Because the page view credits have no expiration date any unused credits for reading or printing can be used in the future.

\section{Online reading}

Students read the e-book pages from files on the e-publisher's server. A subscription allows the student to read a fixed number of pages, and the cumulative count is shown on the screen during access. Once the count reaches the maximum allowed the subscription could be supplemented as needed. Another counter tracks the number of pages printed and printing is disabled after a fixed total number of pages have been printed. As in the case of the downloading option, the free plugin software, ebrary Reader, must be installed on all computers that will be used.

The advantage of the online reading option is that access can be from any machine - university, home, work or roaming. On the other hand, each time a page is accessed it must be transferred to temporary storage on the reader's current computer and this can be a time consuming and costly exercise for the reader. Any page reading credits that the student has not used by the close of the course can be used at a later time.

\section{Method}

\section{Approach to this study}

This study was intended to be exploratory and descriptive in nature. It was opportunistic in the sense that given this was a first endeavour to introduce a new technology into the course, our primary purpose being to gain insights from student feedback on aspects of introducing an e-book that would assist in the future application of this technology. Accordingly, no attempt was made at hypothesis testing to confirm or disconfirm an extant theory. However we acknowledge that Roger's diffusion of innovation 
theory may have provided a possible theoretical underpinning for the study. Any future studies in this area may benefit from using this theoretical framework.

\section{Subject selection}

At the introductory lecture the course convenor explained why and how the reading resources were available online. This included a large screen demonstration by the third author and fielding of student queries relating to online access. Forty students attended the first class but only eighteen chose to continue with the course. This high attrition rate needs clarification. It is not uncommon for postgraduate accounting students to sit in a number of courses during the first week of semester in order to find out more about each course before finalising their enrolment. Admittedly the number withdrawing or deciding not to sign up was more than normal, albeit only marginally higher. Informal feedback from those who chose to withdraw and those who chose to continue indicated a majority of these withdrawing students did so for reasons other than the introduction of an electronic text book. One common reason was that students tended to seek courses that were perceived as soft options and eschewed a course that would appear to impose more demands on their time and effort. Some other students withdrew because they became aware that a higher level of computer literacy and access was expected of them than they possessed.

Taking these factors into consideration, the reduced number of students who finally enrolled was not unexpected. These enrolled students would appropriately constitute our target group of students for the purpose of this study for two reasons: they would have possessed the requisite computer skills in order to adequately assess the use of an electronic text book in learning, and they would be highly motivated to take the course driven by a keen desire to build the foundations for their careers. We therefore did not anticipate an unacceptably biased result from this target sample.

Before semester began the publisher burnt copies of the e-book to CDs. These were intended for distribution only if necessary, and were left with the lecturers. At the second lecture the students' take up of the e-book was so low that, to contain the attrition, they were offered the alternative means of access to the e-book. Thereafter students used Acrobat Reader to read the files on the CDs and there was no restriction on frequency of viewing or printing, and no need to be connected to the Internet while reading files, though the sophisticated tools for note taking and highlighting were not available. 
Data collection

Data input for this study was drawn from three sources. Preliminary discussions were held with the publisher and the university's IT department to investigate the feasibility of mounting an electronic text book in Semester 1, 2004 with two access choices: an online reading option and a downloading option, as explained earlier. The authors, including the two involved in using the electronic text book for teaching, participated in these discussions and the teaching academics provided further inputs during the semester as they moved along the learning curve through their interactions with the students. The authors then constructed a questionnaire to obtain feedback to assess the students' readiness in using an e-book as an alternative learning tool to a printed text book. An independent academic within the university who had expertise with questionnaire design reviewed the questionnaire. After further refinement the final questionnaire was administered to the eighteen students during the second last week of the Semester 1, 2004 by the non-teaching author. The completed questionnaires were placed inside a sealed envelope to be opened only after the students' final course results were officially released. This procedure was undertaken to increase assurance that students would offer their frank and honest opinions on the use of an electronic text book.

The survey used items with a five point, Likert type ordinal scale for ranks (distinct categories), as well as asking for open ended comments to gather additional information on the e-learning experience. For ordinal data the appropriate statistics are medians and percentiles (Hanke \& Reitsch, 1991) because differences between and ratios of these ranks have no meaningful interpretation. As the use of statistical tests involving means, standard deviations and assumptions of normality is inappropriate, a chi-squared non-parametric test, valid with small samples, was used (Rickmers \& Todd, 1967). A statistic was computed to test whether the middle rank was also the median rank. For each survey item, if students' responses to the survey items were neutral, the median rank would be the central rank; otherwise the responses would be skewed to one end of the scale.

While the survey design was used for data collection and analysis, we had benefited immensely through the various stages of the course by having informal discussions and feedback from students about the different aspects of learning, especially the use of the e-book for the course. These qualitative responses by students were useful to guide our preparation of the questionnaire for the survey.

\section{Analysis of results}

The results of the ranked responses to survey items are summarised in Table 1. For each survey item, the five point, Likert type scale and its verbal 
Table 1: Frequency of responses to survey items $(n=18)$

\begin{tabular}{|c|c|c|c|c|c|c|c|}
\hline & Survey items & & $\begin{array}{r}\text { Fr } \\
\text { stude }\end{array}$ & $\begin{array}{l}\text { quenc } \\
\text { ts' res }\end{array}$ & $\begin{array}{l}\text { of } \\
\text { onses }\end{array}$ & & $\begin{array}{c}\text { Chi- } \\
\text { squared }\end{array}$ \\
\hline 1 & $\begin{array}{l}\text { For me, gaining access to a } \\
\text { computer for my study was. }\end{array}$ & $\begin{array}{c}0 \\
\text { diffi- } \\
\text { cult }\end{array}$ & 0 & 3 & 4 & $\begin{array}{c}11 \\
\text { easy }\end{array}$ & 12.50 ** \\
\hline 2 & $\begin{array}{l}\text { Before I began this course I } \\
\text { found web surfing and emailing } \\
\text { was.... }\end{array}$ & $\begin{array}{c}0 \\
\text { diffi- } \\
\text { cult }\end{array}$ & 0 & 1 & 4 & $\begin{array}{c}13 \\
\text { easy }\end{array}$ & $16.06^{* *}$ \\
\hline 3 & $\begin{array}{l}\text { Finding the material I wanted on } \\
\text { the web site was... }\end{array}$ & $\begin{array}{c}0 \\
\text { diffi- } \\
\text { cult }\end{array}$ & 1 & 4 & 3 & $\begin{array}{c}10 \\
\text { easy }\end{array}$ & $8.00^{* *}$ \\
\hline 4 & $\begin{array}{l}\text { Finding the material I wanted on } \\
\text { the e-book was.... }\end{array}$ & $\begin{array}{c}2 \\
\text { diffi- } \\
\text { cult }\end{array}$ & 2 & 7 & 1 & $\begin{array}{c}4 \\
\text { easy }\end{array}$ & 0.06 \\
\hline 5 & $\begin{array}{l}\text { Reading the electronic screen } \\
\text { that displayed the e-book was .. } \\
\text {. }\end{array}$ & $\begin{array}{c}5 \\
\text { diffi- } \\
\text { cult }\end{array}$ & 4 & 3 & 2 & $\begin{array}{c}2 \\
\text { easy }\end{array}$ & 1.56 \\
\hline 6 & $\begin{array}{l}\text { Displaying new screens on the } \\
\text { website and turning the pages of } \\
\text { the e-book was... }\end{array}$ & $\begin{array}{c}3 \\
\text { slow }\end{array}$ & 5 & 6 & 2 & $\begin{array}{c}0 \\
\text { fast }\end{array}$ & 2.25 \\
\hline 7 & $\begin{array}{l}\text { At the beginning of this course, } \\
\text { how did you expect the e-book } \\
\text { would suit your study style? }\end{array}$ & $\begin{array}{l}7 \\
\text { with } \\
\text { diffi- } \\
\text { culty }\end{array}$ & 1 & 4 & 1 & $\begin{array}{c}5 \\
\text { with } \\
\text { ease }\end{array}$ & 0.22 \\
\hline 8 & $\begin{array}{l}\text { You may have expected to have } \\
\text { problems with reading online, } \\
\text { with not being able to highlight } \\
\text { and underline, or perhaps with } \\
\text { the non-portability of the e-book. } \\
\text { Rate your level of concern here: }\end{array}$ & $\begin{array}{c}2 \\
\text { none }\end{array}$ & 1 & 1 & 4 & $\begin{array}{c}10 \\
\text { high }\end{array}$ & $6.72^{* *}$ \\
\hline 9 & $\begin{array}{l}\text { How much of the e-book did you } \\
\text { print to paper? }\end{array}$ & $\begin{array}{c}8 \\
0 \% \\
\end{array}$ & $\begin{array}{c}3 \\
25 \% \\
\end{array}$ & $\begin{array}{c}1 \\
50 \%\end{array}$ & $\begin{array}{c}1 \\
75 \% \\
\end{array}$ & $\begin{array}{c}5 \\
100 \%\end{array}$ & 1.39 \\
\hline 10 & $\begin{array}{l}\text { How easy was it to speed read } \\
\text { and browse the e-book } \\
\text { compared to doing the same in a } \\
\text { printed book? }\end{array}$ & $\begin{array}{c}5 \\
\text { diffi- } \\
\text { cult }\end{array}$ & 3 & 4 & 1 & $\begin{array}{c}2 \\
\text { easy }\end{array}$ & 1.67 \\
\hline 11 & $\begin{array}{l}\text { In future, when deciding } \\
\text { whether to enrol in a course that } \\
\text { has instructions and content } \\
\text { available on the web, I will be ... }\end{array}$ & $\begin{array}{c}0 \\
\text { reluc- } \\
\text { tant }\end{array}$ & 1 & 8 & 2 & $\begin{array}{c}7 \\
\text { keen }\end{array}$ & $3.56^{*}$ \\
\hline 12 & $\begin{array}{l}\text { In future, when deciding } \\
\text { whether to enrol in a course that } \\
\text { uses an e-book, I will be... }\end{array}$ & $\begin{array}{c}6 \\
\text { reluc- } \\
\text { tant }\end{array}$ & 2 & 4 & 3 & $\begin{array}{c}3 \\
\text { keen }\end{array}$ & 0.22 \\
\hline
\end{tabular}

Using chi-squared test for goodness of fit of data to test whether the middle rank is the median rank (1 degree of freedom):

* median rank differs from central rank with $10 \%$ significance,

** median rank differs from central rank with $5 \%$ significance 
anchors are shown, together with the frequency distribution of students' responses.

Access, navigation and ease of reading

The number of students who reported having ready access to computers for their study (Item 1) was significantly higher than 'neutral', with none of those enrolled reporting a perceived difficulty. Students also deemed their pre-existing Internet and email familiarity (Item 2) to be significantly higher than 'neutral'. These results implied that students were computer literate at the time of enrolling for the course. Further, the students reported significantly easy navigation (Item 3) around the course's online site. The students therefore could be expected to be sufficiently proficient in finding material on the e-book site because no higher computer skill was required than what they already possessed.

Despite students having these computer skills, the number who had difficulty finding material on the e-book site was balanced by the number who thought it easy (Item 4), and many students were non-committal about the ease of navigation around the site (note that the responses to Item 4 refer to the e-book site, not the course's online site). The wideness of the range of responses to Item 4 indicates that navigation was easy for some and difficult for others, despite their pre-existing skills. This seems to indicate that, while the text book publishers have taken steps to have their products available electronically, their online interfaces with clients need further refinement to increase their appeal.

The students' assessments of the actual experiences of reading the e-book on screen (Item 5), page turning (Item 6) and browsing (Item 10) were tending towards the negative pole. Their responses ranged from difficult to easy for all three tasks and none had a median that differed significantly from 'neutral'. These responses referred only to the CD based PDF files of the e-book that students received and used after the first week of the semester. They did not refer to the online or to use these versions that had been set up for them. A couple of students responded negatively to the use of the e-book because of difficulty with reading the screen for prolonged periods. A query on the ease of reading online elicited mixed comments such as these:

It was easy to read but difficult to write notes.

There are better ways of doing an e-book instead of e-pdf. Check for instance the MS Reader with 'clear font' and sizable size. That reads very well.

Access was a problem for one student who reported that his office computer would not allow him access to the e-book because of a firewall restriction. One found the process too slow and the cost too high. Another 
commented: "As the e-book was online on computer, it was not as portable/easy to access as a traditional text book."

\section{Learning styles}

Item 7 in Table 1 sought students' expectations of whether the e-book would suit their style of study. The responses showed that students' expectations of success with the e-book were evenly spread - roughly a third of them had high expectations that their study style could be accommodated, a third were neutral and a third had low expectations. The related Item 8 asked whether students would have anticipated problems due to inability to use their printed book study techniques in an online setting, and a significant majority responded that they had encountered a problem. Our concern was that their pre-dispositions may affect their acceptance of the e-book, and their end of course memory of their attitude at the beginning indicates that, as they had no prior exposure to using an ebook, many were approaching the course with misgivings and at least had mixed feelings about the ease of using the tool.

Regarding the change needed in study technique, one student wrote: "As the e-book was new, I was unsure about how to approach summarising the material, then reviewing the material from the e-book."

We also queried whether students transferred the material to paper (Item 9). While nearly half the class managed without a paper version the others printed at least some parts of the e-book, but the median amount printed did not differ significantly from $50 \%$. We found through informal feedback that students printed only those pages that related to topics they encountered difficulty in understanding and which needed thorough rereading. This being the case, it would appear that an e-book might be a definite advantage from a cost perspective over the traditional text book, if it was available, that could only be purchased whole at a higher cost. This was actually the view of one student who listed as one of the positive experiences of using an e-book that it was "Economical (no need to buy expensive books)".

The narrative feedback in Table 2 reports students' positive and negative comments on the CD e-book.

Did interest in the course override their perceived difficulties?

Students were asked for feedback on why they had continued with the course when others had dropped out after the first lecture and on whether there had been any positive or negative experiences with the electronic medium. This feedback sought to ascertain whether students were 
interested in the subject and accepted the e-book as part of the course offering. Typical responses were as follows:

I enjoyed the subject and knew a way around the e-book would be found.

Because I was confident that the lecture can contribute value to my study program.

I was interested in the topic, particularly the combination of entrepreneurship and business strategy.

Because, although it is a very difficult subject, it will be very useful for my future career .... I have not learnt so much about this type of subject before.

Table 2: Experiences with the Internet and e-book in a postgraduate accounting course

\begin{tabular}{|c|c|}
\hline Positive experiences & Negative experiences \\
\hline $\begin{array}{l}\text { 1. Highlights importance of electronic } \\
\text { learning }\end{array}$ & $\begin{array}{l}\text { 1. Web is difficult to access with dialup } \\
\text { modem }\end{array}$ \\
\hline $\begin{array}{l}\text { 2. Web allowed me to find all } \\
\text { document needed }\end{array}$ & $\begin{array}{l}\text { 2. Scanned documents in pdf take a } \\
\text { long time }\end{array}$ \\
\hline 3. I can do stuff at work & 3. Lacking in technology \\
\hline $\begin{array}{l}\text { 4. Print and not photocopy (photo- } \\
\text { copying at the university is too slow) }\end{array}$ & 4. Lacking in usability \\
\hline 5. Easy to access documents & $\begin{array}{l}\text { 5. Not comfortable with reading on } \\
\text { screen }\end{array}$ \\
\hline 6. Portability & $\begin{array}{l}\text { 6. Difficulty with printing from online } \\
\text { version - only } 10 \text { pages at a time }\end{array}$ \\
\hline 7. Fast information flow & $\begin{array}{l}\text { 7. Reading speed is faster with normal } \\
\text { book }\end{array}$ \\
\hline 8. Paperless & 8. Impossible to take notes \\
\hline 9. Flexibility & 9. e-book is expensive and slow \\
\hline 10. Highlighting and redo possible & $\begin{array}{l}\text { 10. Different and more challenging } \\
\text { learning process }\end{array}$ \\
\hline $\begin{array}{l}\text { 11. Easy access of readings, schedules } \\
\text { with web }\end{array}$ & $\begin{array}{l}\text { 11. Requires specific versions of Adobe } \\
\text { to work effectively with it }\end{array}$ \\
\hline $\begin{array}{l}\text { 12. Can check outline and lecture notes } \\
\text { easily }\end{array}$ & $\begin{array}{l}\text { 12. Some documents too heavy for a } \\
\text { floppy disk }\end{array}$ \\
\hline $\begin{array}{l}\text { 13. Up to date information available on } \\
\text { web }\end{array}$ & 13. Big files to download from web \\
\hline 14. Learning how to search & 14. Inconvenient to work off line \\
\hline $\begin{array}{l}\text { 15. Using computer and web more } \\
\text { efficient }\end{array}$ & $\begin{array}{l}\text { 15. Hurts eyes when reading too long on } \\
\text { the computer }\end{array}$ \\
\hline $\begin{array}{l}\text { 16. Economical (no need to buy } \\
\text { expensive books) }\end{array}$ & $\begin{array}{l}\text { 16. Difficult for flip between three } \\
\text { different articles on one acrobat } \\
\text { reader }\end{array}$ \\
\hline $\begin{array}{l}\text { 17. Interactive (more "fun") } \\
\text { 18. Improve my reading skill }\end{array}$ & \\
\hline
\end{tabular}


Several students commented that the subject itself was demanding and involved the added difficulty of having to access the electronic text book, but agreed that they found it both interesting and challenging.

\section{Overall assessment}

Interestingly, a significant number of students appear to be keen to use Internet features (Item 11) in their study again, but reactions to the prospect of using another e-book (Item 12) were spread flatly from reluctance to keenness with no significant numbers at either extreme.

Table 3 presents students' perception of the influence of the electronic delivery on the effectiveness of their learning. The comments are grouped by perceived effectiveness - positive effect, negative effect and without effect.

Table 3: Extent to which electronic delivery influenced learning effectiveness

\begin{tabular}{|l|l|}
\hline & \multicolumn{1}{|c|}{ Students' comments } \\
\hline $\begin{array}{l}\text { Positively } \\
\text { influenced }\end{array}$ & $\begin{array}{l}\text { Cannot read the book online, so need to have it printed. However, it } \\
\text { does allow for combining best bits for the course. } \\
\text { It contains all the information and material I need. I like it. } \\
\text { It introduces a sort of interactivity in studying. }\end{array}$ \\
\hline $\begin{array}{l}\text { Negatively } \\
\text { influenced }\end{array}$ & $\begin{array}{l}\text { The e-book did not save time but created additional wasted time. } \\
\text { Reading was harder and I had to skip some parts. } \\
\text { I very much prefer to use a hard copy of a text book as it is easier to } \\
\text { read, highlight and study from. } \\
\text { Might have slowed it down a tad. }\end{array}$ \\
\hline No influence & $\begin{array}{l}\text { The electronic delivery did not influence my learning in a positive or } \\
\text { negative manner. } \\
\text { It did not help me much. }\end{array}$ \\
\hline
\end{tabular}

\section{Discussion}

Given that this was our first attempt at producing an e-book for use in a postgraduate accounting course, the results appear encouraging. Overall, student perceptions were either positive or were indifferent, rather than definitely negative. The notion of using an e-book as an alternative learning tool was therefore generally favourably received. Informal feedback obtained by the two teaching academics also attested to this conclusion. However, there were some students who had expressed reservations about the e-book's efficacy as a learning tool. We attribute this partly to a lack of exposure by these students to electronic delivery of a book, and possibly 
for this reason, there might be a certain level of apprehension as some students found it a challenge coping in an online learning environment. If initial resistance was the reason for this caution, it could be overcome with time as students become more familiar with the new learning tool. While this observation might seem contradictory to the finding that all enrolled students possessed reasonable computer literacy, and therefore should have been more receptive to the use of an e-book, we could only conclude that the perceptions and actuality of non-portability and reluctance to adapt learning strategy were paramount, but access to the Internet was not problematic. Portability is becoming less of an issue as computers become lighter in weight and as wireless reception becomes more widespread. Had the students persisted with use of the online e-book they would have been exposed to highlighting and note taking tools that would emulate their paper based learning techniques. Without these tools and in retrospect it would have been helpful to offer students instruction in using the reader as well as techniques for improving legibility of the page images.

The evidence from this survey also suggests that any reservations about using an e-book as a learning tool are largely technology focused and to a lesser extent a consequence of student hesitation to modify their study behaviour toward using the e-book for learning. Accordingly, related technology issues are discussed next. Our experience leads us to support the findings of Kirkwood and Price (2005) and Judson and Sawada (2002), that it is the educational purpose and pedagogy that drive new forms of teaching and learning, not technologies. However, the current state of ebook technology could impede rather than enhance e-learning. Accordingly, related technology issues are discussed next.

\section{Technology issues}

This study reaffirmed the technical problems raised by Thurstun (2000) concerning online learning. When producing an e-book it is important to recognise the difficulties experienced by readers and to adjust writing styles and visual effects in order to minimise or eliminate these difficulties. As the e-book used by our students was print online and was not given a new layout or re-working to suit the electronic medium, we found our students encountered similar problems. Online screens, whether via Internet or CD, were images of printed pages. The fonts were too small for easy reading and resizing them on screen was possible but annoying and distracting. Turning pages back and forth online was not as quick as with paper. In addition, there was not enough white space on the screen to counteract the distraction of colour and the clutter of the page content. There is also a need for quality screens with no flicker. 
We suggest that online publishers should first suitably reformat for electronic viewing the material that they originally configured for print. Traditionally students feel free to underline, highlight and annotate what they consider noteworthy; they turn page corners, begin at a randomly chosen page in the book, browse and select only pages that interest them until a more thorough perusal becomes necessary for their comprehension. For a successful transition to online use, all these tools should be available electronically otherwise the students' impulse to print the e-book becomes compelling.

Distance learning students, who traditionally receive printed material at the start of each course, will find electronic access a bonus. However, changing from print to electronic material requires that the student's Internet server and telephone lines or cable need to be able to bear the load and, again, the student's computer would need to have enough power and memory and the appropriate software. At present the connection speeds for many Asian countries are low enough to discourage use of the Internet for delivery, and using mirror sites creates the problems and expense of hosting and maintenance.

For study purposes students use computers at their university, homes, work office, local library or Internet café, or they may use a laptop plugged in at a friend's house or a hotel room. Many of these locations are unsuitable for downloading the e-book because of restrictions placed on writing to hard drives of institutional computers. Whether a subscription is for downloading or online reading, the software for screen reading and monitoring accesses must be installed within the program file folders on the hard drive. Only the administrators of machines in most universities, work places, libraries and Internet cafés can download the plugin software to these folders. Further, institutional computers are subject to regular purges of temporary files so working files must be on removable disks or USB drives.

Whichever option is chosen, the computer must connect to the Internet, and consequently students who live on shoestring budgets and rely on the university for Internet access would need to use the university computers. Many of our university's student computers have enforced time limits of five to sixty minutes, and these limits allow insufficient time for intensive reading and study of a topic. Consequently, special arrangements would need to be made with administrators of computer laboratories for extended times. We suggest that the university policy on student access to computers should be reviewed to accommodate download to hard drives, long term storage of files, and increases in user time allocations. 
Based on these discussions and the suggestions made from our study, it is clear that the technology imperatives should be firmly established before the e-book can become a friendly and effective mode of study.

\section{A mindset change toward e-book learning}

Students who have been used to reading via paper books will need to adapt their techniques when reading from an electronic screen. While, at least initially, some might resist this change, our study concluded that this should not be a major problem compared to the technological issues. As pointed out by Hartley (2002), attitudes to reading large amounts of text online are probably changing, and young readers of today seem more willing than older ones to read and comprehend large amounts of online text. Despite this optimism, Galbreath (2001) believes that change on the part of all the actors affected by the e-book is the biggest issue in making the e-book an important educational technology. However, our postgraduate accounting student sample was largely in the twenty-plus age group and, from our survey responses, there was no strong evidence of total rejection of the e-book as a learning tool, suggesting that the change Galbreath refers to is already under way, at least on the part of students.

The cost advantage of using an e-book also predisposed students to be more receptive to the idea of electronic delivery since only pages that they considered relevant to their needs would be printed. This ability to selectively print would result in large cost savings. Moreover, many institutions choose to pass on the cost of printing to students by bundling handouts, case studies and laboratory notes, and selling these bundles at the commencement of each course. All planned class handouts could also be included in the publication and delivered electronically. Students who are prepared to read online then can avoid the cost of printing.

\section{Limitations and future research}

Interpretation of the findings must be tempered by the following limitations. Firstly, the small sample size does not permit generalisability of the results. As there were only eighteen students enrolled it was not possible to stratify the sample based on, for example, each student's country of origin. It is expected that students who come from technologically less developed countries might find using the e-book more intimidating than those who come from technologically more advanced countries. Secondly, a formal survey questionnaire should have been administered at the start of the course, instead of relying on informal feedback, so that a more meaningful comparison could be made to assess changes in expectations regarding the use of the e-book. Thirdly, it has 
been a goal of this university to expand educational opportunities to elearning as a full fledged complement to campus learning within the foreseeable future. So, when some of the technical issues with the e-book have been resolved, both at the publisher and at the university level, adoption is expected to be undertaken with greater vigour and there would then be an increased focus on more innovative ways of using an e-book as part of a broader educational design to enhance learning. Associated research should explore in greater depth the impact on student learning outcomes through a combination of technology and pedagogical practices.

\section{Summary and conclusion}

This paper summarises our initiative with constructing an electronic text book for use by students in a postgraduate accounting course, with the specific purpose of examining the issues of student and technical readiness to utilise this medium as an alternative learning tool. The results reveal that student computer literacy, while a requisite, is not a sufficient condition in ensuring successful implementation of online text book learning. This study finds the major impediment to online learning using an e-book is technology based, specifically the lack of user friendly software. To a lesser extent, there is also a need to manage and change student mindsets and their expectations of using this new learning tool.

The insights gained from the experience of this experiential study, even though they are based on a very small sample of students, could have important policy implications for academics and tertiary institutions in developing sound strategies in these areas as suggested in the paper. Since the concept of virtual or borderless universities will very likely underpin the education of the future, progressive universities must recognise the pitfalls of hastily embracing online learning without first putting in place the essential computer technology and related infrastructural facilities in order to achieve the desired online learning outcomes.

\section{Acknowledgements}

This article is an expanded and revised version of a previously published article, Kropman, Schoch and Teoh (2004). An earlier version of this article was presented at the 28th Annual Congress of the European Accounting Association, Sweden, May 2005, and the authors wish to acknowledge the useful comments received from Congress participants.

http://www.handels.gu.se/eaa2005/Paper_Poster_database/AED/AED0 07_abstract.htm 


\section{References}

Adobe Reader (2006). [verified 23 Mar 2006] http://www.adobe.com/products/acrobat/readermain.html

Alexander, R. (1996), Teaching good systems design for spreadsheet projects. Journal of Accounting Education, 14 (Spring), 113-122.

Amazon.com (2006). [verified 23 Mar 2006] http:/ /www.amazon.com/

Ardito, S. (2000). Electronic books: To "E" or not to " $E$ ", that is the question. Searcher, 8(4), 1-12.

Armatas, C., Holt, D. \& Rice, M. (2003). Impacts of online-supported resource based learning environment: Does one size fit all? Distance Education, 24(2), 141-158.

Birnbaum, B. (2004). The case for online course packs and e-books. Campus Technology's eLearning Dialogue. [verified 28 Oct 2004]

http:/ / www.campustechnology.com/news_article.asp?id=9468\&typeid=155

Bryant, S. \& Hunton, J. (2000). The use of technology in the delivery of instruction: Implications for accounting education researchers. Issues in Accounting Education, 15(1), 129-162.

Carr-Chellman, A. \& Duschatel, P. (2000). The ideal online course. British Journal of Educational Technology, 31(3), 23-245.

Coppage, R. E., Sriram, R. \& Baxedale, S. (1996), Perceived effectiveness of integrating computers into accounting curriculum. The Accounting Educators Journal, 8(Fall), 1-12.

Davies, K., Fitzsimmons, A. \& MacLeod, E. (2001). "In the beginning, there were ebooks?" A brief history of the e-book revolution. SoCbytes Journal, 1(2). [verified 13 Jun 2006] http:/ / www.dcs.napier.ac.uk/ mm/socbytes/jun2001/Jun2001_8.htm

De Lange, P., Suwardy, T. \& Mavondo, F. (2003). Integrating a virtual learning environment into an introductory accounting course: Determinants of student motivation. Accounting Education, 12(1), 1-14.

ebrary (2006). [verified 23 Mar 2006] http:/ /www.ebrary.com/

Galbreath, J. (2001). The e-book: Technological promise for learning, Educational Technology, 41(4), 54-56.

Gemstar eBook (2003). [verified 23 Mar 2006]

http://www.gemstar-ebook.com/ebcontent/devices/default.asp

Hanke, J. \& Reitsch, A. (1991). Understanding business statistics. Irwin, Boston, MA.

Hartley, J. (2002). Is judging text on screen different from judging text in print? A naturalistic e-mail experiment. Innovations in Education and Teaching International, 39(1), 21-25. 
Judson, W. \& Sawada, D. (2002). Learning from past and present: electronic response systems in college lecture halls. Journal of Computers in Mathematics and Science Teaching, 21(2), 167-181.

Kennedy, S. (2000). Getting cozy with a good e-book? Information Today, 17(6), 48-49.

Kirkwood, A. \& Price, L. (2005), Learners in the twenty-first century: What do we know about students' attitudes and experiences of information and communication technologies that will help us design courses. Studies in Higher Education, 30(3), 257-274.

Kropman, M., Schoch, H.P. \& Teoh, H.Y. (2004). An experience in e-learning: Using an electronic textbook. In R. Atkinson, C. McBeath, D. Jonas-Dwyer \& R. Phillips (Eds), Beyond the comfort zone: Proceedings of the 21st ASCILITE Conference (pp. 512-515). Perth, 5-8 December.

http:/ / www.ascilite.org.au/conferences/perth04/procs/kropman.html

Looney, M. A. \& Sheehan, M. (2001). Digitizing education: A primer on e-books. EDUCAUSE Review, 36(4), 38-46. [verified 9 May 2006] http:/ / www.educause.edu/ir/library/pdf/erm0142.pdf

McNaught, C., Burd, A., Whithear, K, Prescott, J. \& Browning, G. (2003). It takes more than metadata and stories of success: Understanding barriers to reuse of computer facilitated learning resources. Australian Journal of Educational Technology, 19(1), 72-86. http:/ / www.ascilite.org.au/ajet/ajet19/mcnaught.html

Microsoft Reader (2003). [verified 23 Mar 2006] http://www.microsoft.com/reader/uk/default.asp

Oliver, B. \& Wright, F. (2002). The next big thing? Exploiting channels and handheld computers for student learning. Teaching and Learning Forum 2002. [verified 9 May 2006] http:/ / www.ecu.edu.au/conferences/tlf/2002/pub/docs/Oliver.pdf

Project Gutenberg (2005). [verified 23 Mar 2006] http://gutenberg.net/faq/

Reeves, T. (1997). Evaluating what really matters in computer-based education. [originally published at http://www.educationau.edu.au/archives/cp/reeves.htm; see http://www.educationau.edu.au/jahia/Jahia/pid/179 or http://www.medicine.mcgill.ca/ibroedu/review/Reeves\%20Evaluating\%20What\%20Re ally\%20Matters\%20in\%20Computer-Based\%20Education.htm]

Rickmers, A. \& Todd, H. (1967). Statistics: An introduction. McGraw-Hill, Inc. New York.

Safari Books Online (2005). [verified 23 Mar 2006] http:/ / www.safaribooksonline.com/

Sangster, A. \& Lymer, A. (1998). How to survive a new educational era. Issues in Accounting Education, 13(4), 1095-1109.

Taylor \& Francis eBookstore (2001). [viewed 8 Nov 2004] http:/ / www.ebookstore.tandf.co.uk/ 
Thurstun, J. (2000). Screenreading: Challenges of the new literacies. Information Technology, Education and Society, 1(1), 39-55.

VitalSource (2005). [verified 23 Mar 2006] http:/ / www.vitalsource.com/

Wikipedia (2006). [verified 23 Mar 2006] http:/ / en.wikipedia.org/wiki/Ebook

Wood, M., Cahill, P. \& Hicks, J. R. (1997). Computer packages as cognitive paradigms: Implications for the education of accountants. Journal of Accounting Education, 15(1), 53-69.

Herbert P. Schoch, Department of Accounting and Finance Macquarie University NSW 2109, Australia.

Email: herbert.schoch@mq.edu.au

Hai Yap Teoh, Department of Accounting and Finance

Macquarie University NSW 2109, Australia

Margaret Kropman, Centre for Flexible Learning

Macquarie University NSW 2109, Australia.

Email: margaret.kropman@mq.edu.au 